Ambiances

anbiances Environnement sensible, architecture et espace urbain

$7 \mid 2021$

Staging Atmospheres: Theatre and the

Atmospheric Turn - Volume 2

\title{
Aural Attunement is a form of performative writing used to write about nonhuman affective relations in Emma Bennett's Slideshow Birdshow (2013)
}

L'accordage auditive est une forme d'écriture performative utilisée pour écrire à propos des relations affectives non humaines dans Slideshow Birdshow (2013)

d'Emma Bennett

Rebecca Collins

\section{OpenEdition}

Journals

Electronic version

URL: https://journals.openedition.org/ambiances/4047

DOI: 10.4000/ambiances.4047

ISSN: 2266-839X

Publisher:

Direction Générale des Patrimoines - DAPA - MCC, UMR 1563 - Ambiances Architectures Urbanités (AAU)

Electronic reference

Rebecca Collins, "Aural Attunement is a form of performative writing used to write about nonhuman affective relations in Emma Bennett's Slideshow Birdshow (2013) ", Ambiances [Online], 7 | 2021, Online since 22 December 2021, connection on 24 December 2021. URL: http://journals.openedition.org/ ambiances/4047 ; DOI: https://doi.org/10.4000/ambiances.4047

This text was automatically generated on 24 December 2021.

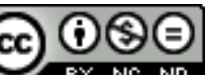

Ambiances is licensed under a Creative Commons Attribution-NonCommercial-NoDerivatives 4.0 International License. 


\section{Aural Attunement is a form of performative writing used to write about nonhuman affective relations in Emma Bennett's Slideshow Birdshow (2013)}

L'accordage auditive est une forme d'écriture performative utilisée pour écrire à propos des relations affectives non humaines dans Slideshow Birdshow (2013) d'Emma Bennett

Rebecca Collins

\section{What happens?}

The cultivation of attention to the complexities of force, feeling, atmosphere and affect found in the plurality of everyday experience is a central concern for artists and human geographers alike. These ephemeral, often unnameable, aspects of our daily lives have been described by Nigel Thrift as 'the geography of what happens' (2008, p.2) and form part of ongoing endeavours to articulate the relational and social dimensions of life as 'non-representational' or 'more-than-representational' (Lorimer, 2005). It is the gap between word and world, the 'how' of appearance, detected in the shortcomings of representation that non-representational theory takes issue with. Whilst this has been a central concern of human geography since the late 1990s and early 2000s, forms of bodily sensing and its subsequent articulation inform concerns central to performance studies and artistic practice. Indeed, artistic practice, in both process and presentation, is often concerned with attuning to the circulation of feelings and thereby can critically challenge, via embodied means, the taken-for-granted foundations of thought and relations (Spatz, 2015; 2019). In this article I ask how might performative writing, informed by a framework of aural attunement, enable further comprehension of non- 
representational theory? And, in turn, what might performative writing, and aural attunement, learn from non-representational theory?

Non-representational theory highlights the inadequate means we have for articulating experience and our relation with the world. Human geographer, J-D Dewsbury, in 'Language and the Event: The Unthought of Appearing Worlds' (2010), notes that nonrepresentational theory deals with how the world appears to us. Dewsbury warns against completely abandoning habitual forms of mediation found in the signs, systems, rules, codes and technologies essential to language use and meaning making despite their limitations (ibid., p.148). Instead, he encourages the cultivation of awareness toward how such tools mediate and ultimately orientate our relation to the world. One of the central queries posed by Dewsbury relates precisely to how we are to critique the tools of mediation we rely on to make sense of the world or, at the very least, how to expose their inadequacies (ibid., p. 149). If, as Dewsbury notes, the nonrepresentational frame is always 'bent towards the artistic more than the social scientific' (ibid., p. 155) it follows that geographers (with all due respect) might not be best equipped to articulate experience as a thinking-doing.

Experimental and embodied approaches found in contemporary performance practice are well-placed to highlight shortcomings in the representation of life in relation to containment and social construction. Artist geographers Candice P. Boyd and Christian Edwardes, in their recent publication Creative Practice and the Non-Representational (2019), indicate how non-representational theory is crucial for process-based understandings of the world' (ibid., p. 3). This, they argue, lends itself well to creative practice which is concerned with 'carnal, bodily, or visceral knowledges'. The varied approaches artists take to feel their way through form(s) and the how of (re)presentation are essential to the practice of contemporary performance, as form and content are continually queried. In this article, I make use of aural attunement to explore how performative writing can articulate the unstable, or uncertain, qualities of experience and sense-making. To do so I focus on Slideshow Birdshow (2013), a solo performance piece by artist researcher Emma Bennett.

Slideshow Birdshow, initiated in 2011, described on Bennett's website as 'a score for voice and uncooperative slideshow', forms part of her ongoing investigative practice into birdsong, mistranslations and the slippages occurring in modes of visual and verbal communication. The piece has been shown at The Basement, Brighton (2012), The Gulbenkian in Canterbury (2012), BLOP at Arnolfini (2012), Forest Fringe at The Gate, London (2012, Interrogate Festival in Dartington (2012), Whitstable Biennale (2012) and In Between Time (IBT) International Festival of Performance (2013). Earlier explorations under the title of BirdTalk were shared with audiences at the Nightingale Theatre in Brighton. The piece has also aired on Resonance FM for 'The Voice Symposium' (2012) and BBC Radio Three's The Verb (2012). Bennett's work investigates the politics of speech as a material for composition often using humour to explore the form and feel of language. More recent works include Iamthemakeup (2014) in collaboration with Holly Pester, WHAT MATTER (2016) and Accent (2017) in collaboration with Antonia Barnett-McIntosh. By writing closely through my own experience of attending Slideshow Birdshow as a listening-spectator and my re-experience of the piece through documentation, I aim to evidence how this performance, in the staging of images, the use of text and voice, offers an engagement with the affective, tactile means through 
which we might reconsider our relationship with nonhuman species and our nonrepresentational engagement with the world.

\section{Aural Attunement as Performative Writing}

5 Attunement describes a turning toward, or into, certain forces, feelings or intensities. The sharpening (or loosening) of attention toward certain phenomena over others. A gradual orientation that takes place over time. Anthropologist Kathleen Stewart in her article 'Atmospheric Attunements' (2011) proposes attunement as a means for conferring analytic attention on the forces, feelings, emotions, objects and relations in circulation within everyday life situations. All of which, Stewart claims, contribute to the feeling, or sense of being in something. The haptic form of writing, deployed by Stewart, puts Thrift's articulation of 'what happens' (2008, p. 2) to work, evidencing how worlding comes about. Stewart, by tracing this in specific instances such as the sound of bees, or the shape of a pocket is able to articulate, via her writing practice, how 'qualities, rhythms, forces, relations, and movements' (2011, p. 445) shape our malleable ways of life thereby causing us to attune to certain ways of living over others. Influenced by the work of Stewart, aural attunement describes an embodied approach to writing about contemporary performance practice. It is commensurate with performative writing and methods within queer theory which privilege attention to resonances of lived embodiment for world-making. As Peggy Phelan notes, performative writing aims to 'enact the affective force of the performance event again' (1997, p. 12) and can be characterised by the use of distinct formats of address embracing the poetic, the intersubjective, the embodied and the haptic (Phelan, 1997; Pollock, 1998). In short, tools to query normative writing practices.

6 Aural attunement seeks to suspend representational thought and linger longer with uncertainty. As listening-spectator I aim to convey my experience of attending Slideshow Birdshow by writing with, rather than writing about. This position is situated and subjective and follows theatre scholar George Home-Cooks' recognition for the need for such practices as, by citing Alva Noë, he recognises that 'perception is [...] something we do' (2004, p.4 cited in Home-Cook, 2015, p. 5). Listening here is understood as a practice conducted with the whole body as opposed to one solely undertaken by the ear as an isolated body part. This follows philosopher Michel Serres in The Five Senses (2016) who argues for our whole body to be conceived as an ear,

we hear through our skin and feet. We hear through our skull, abdomen and thorax. We hear through our muscles, nerves and tendons. Our body-box, strung tight, is covered head to toe with a tympanum. (ibid., p. 141)

7 In sum, as Serres further notes, it is as though 'our whole posture is linked to our sense of hearing' (ibid., 142). As a sensorial apparatus we are well equipped to attend to the affective forms generated by sound, alongside timbre, tone, and texture. By occupying and embodying this position I aim to suspend representational thought thereby cultivating acts of lingering longer with uncertainty. Such is, in part, the project of comparative literature scholar Rei Terada in Looking Away Phenomenality and Dissatisfaction, Kant to Adorno (2009). Terada develops the 'phenomenophile' (ibid., p. 18), a figure who wishes to avoid endorsing the world by lingering longer in looking, or looking away at the shadow on the wall, and 'phenomenophilia' (ibid., p.4), a state which articulates the desire to remain in the (often unshareable) suspensive, illusory 
and ephemeral moments of perception. Revisiting debates on appearance and reality, Terada is highlighting the difficulties of dealing with 'the given world' (ibid., p. 16). The phenomenophilic modes of being she suggests aim to avoid acceptance of the world as is. Terada's discussion is predominantly concerned with Coleridge's preoccupation with phenomenal spectra and debates within visual studies. I am interested in considering how Terada's concepts might inform aural attunement as it describes a form of perception akin to a mode of being-with (rather than being-about). The sense of beingwith that this, and my performative writing proposes, aims to gesture toward how our relations, in this case with the nonhuman species (birds), can extend feelings of wonder and the experience of incommensurable intensities irreducible to linguistic units. Aural attunement as a means to write through my experience of Slideshow Birdshow therefore aims to emulate the process-orientated mode of experiencing live work, endorsing acts of lingering in the perceptive moment and thereby questioning habitual forms of description and analysis.

In more practical terms, my performative writing derives from my first-hand experience of the piece and field notes taken during and after experiencing the work in the auditorium. More recently I have returned to Slideshow Birdshow via text, video, and image documentation provided by the artist. By attending both to the work and its documentation I aim to air the impressions and sensations left lingering on my body thereby tapping into the affective force of the piece. I use this to inform my position as listening-spectator. This study is drawn from a larger corpus of works and is part of my ongoing research into listening and contemporary performance (Collins, 2017; 2018; Collins \& Linsley, 2019).

\section{What we don't know about birdness}

9 February 2013. I am in Bristol for In Between Time (IBT) International Festival of Performance produced by Helen Cole and Helen Davies. The auditorium is dark Emma Bennett stands alone downstage left. A metal music stand supports her words, behind her is a large projection screen. The screen is black. The image of a slightly out of focus bird, small and brownish appears on the first slide perched on a background of green grass; Bennett states, 'This is a bird'. The black screen returns, a longer than comfortable pause ensues before the same slide reappears and Bennett repeats, 'This is a bird'. The black screen returns once more followed by a deep cough. Bennett quickly adds, 'This is a talk about (pause) birds', the same slide with the bird reappears - only this time, the frame has shifted to focus on its body, obscuring its beak. Bennett repeats, 'This is a bird'. Grainy slides of what we are told is a crow, a sparrow, a thrush and a bunting flash up quickly on screen. As each bird is introduced, there is a slight pause before its name is pronounced, 'this is a (pause) crow'. The screen freezes showing a sparrow and a further cough is issued. The repetitive use of basic categorical distinctions deployed in the opening sequence of Slideshow Birdshow highlight the limited function of merely naming or describing, and imply a dissatisfaction with words to account for what is seen. From the outset the deliberate pause, the cough, and choice of poor images evidence the preoccupation of this work with the how of representation indicating, in an embodied format, what we don't know, or are unable to articulate about birdness. 


\section{Attuning attention to the experience of being bird}

Movement is generated in the images on screen as birds and fragments of their body parts appear and disappear, independent of the performer's voice. The images flicker and vibrate on the projection screen exuding a radiant lightness from their pixelated imperfection exhibiting resistance to being solid and gathered. Noticeable movement generated in the sequence of still images encourages a lingering, uncertain glance from the audience, cultivating blurry visions of brown, green, grey and black (barely identifiable) fuzz. Bennett is making us look at our looking, at the way pictures appear to us. Attention is drawn to all the slight idiosyncrasies particular to these small creatures with images far from the neat drawings of birds you might habitually find published in ornithological handbooks or field guide classificatory systems. These blurred images are of a different order - some are clumsy close-ups preventing the whole bird from fitting the frame - its beak or body remains just out of view - at times the whole screen fills with the intricate, close-up, detail of feathers, a tail, a foot. Neat, controlled slides containing clear explanations have been exchanged for this jittery set as Bennett (see Figure 1), making deliberate use of this, attunes our attention to the experience of being bird.

Figure 1: These blurred images are of a different order, Thrush-ish

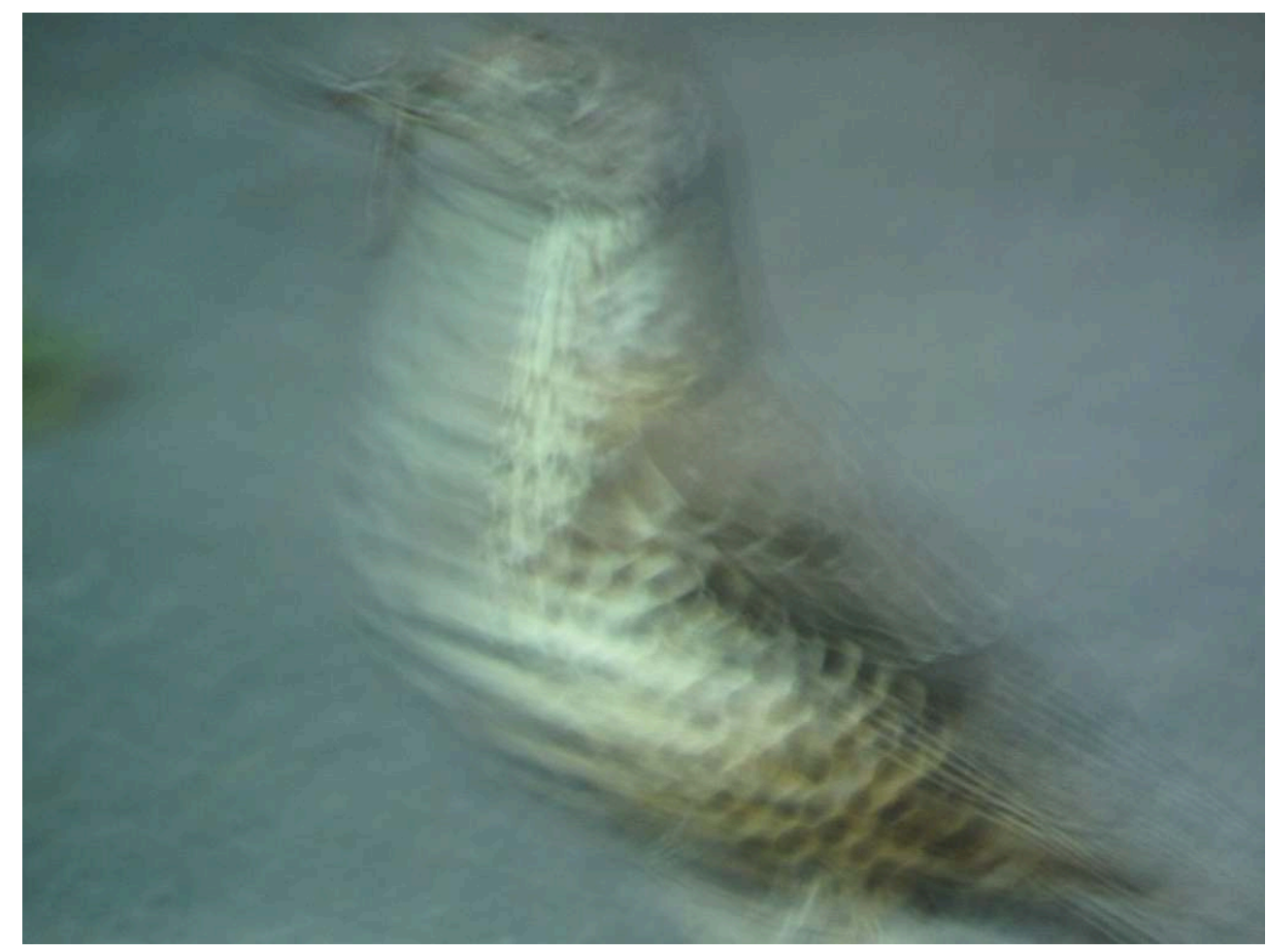

Source: Email Correspondence with Emma Bennett. Copyright: Emma Bennett.

11 As the visual depictions of birds and their body parts cut in and out of focus; our gaze, as audience, is attuned to a worldview far from stable. This occurs through the forms of attention and inattention that are actively elicited by the irregular functions of the presentation display but also via Bennett's vocal accompaniments. The camera angles and the unpredictable rhythmical quality of the slides continually surprises, drawing 
attention to the camera as a mechanism of perception. Each shot draws out the perceptive moment, allowing us, as audience members, to linger longer. Technology, as used here, does not capture or confirm, it serves to question the presumed stability of our perceptive capabilities probing at our desire to know and classify. It is the space, between phenomena or thing itself, and our understanding of it that Bennett's practice occupies. The simple staging choices made by Bennett - the use of a music stand and a slide show (which remain constant throughout) - encourage us, as audience, to attune our focus to their usage in relation to the content. The combination of these elements makes us question how we are framing experience and hints at our tendency to grasp and clarify the world around us.

\section{Lingering Longer}

12 Bennett's wavering, at times trembling voice, attempts to underpin the images we see adding a vibratory aspect to the staging. Distance and pace is instilled as the delivery of words increases in speed just before a pause as a species is named: 'this is a (pause) crow, this is a (pause) , this is a (pause) sparrow'. Both pause and tremble indicate a reluctance to endorse what appears, revealing an inclination to remain in what Terada terms as 'object perception' (2009, p.15). Terada makes a distinction between 'object perception' and 'fact perception' (ibid.). The former implies dissatisfaction with how the world is classified, indicating a preference to linger, lifted from the obligation to categorise and a reluctance to share and reduce the experiential into language. The latter classifies what is seen, for example - a bird has crossed my line of vision. Emma Bennett seems to actively embed lingering into her dramaturgy via the use of object perception. In doing so she is drawing our attention, as audience, to our capacity to spend time in the moment of perception without feeling the urgent necessity to classify, or name, what is being perceived.

Oscillation between fact perception and object perception occurs throughout Slideshow Birdshow; specific bird names, such as 'chaffinch', 'sparrow' and 'bunting' are repeatedly used; yet, there are other moments which clearly escape definition or classification, marked by sounds such as 'uh, uh', 'In fliii'. These are sounds which almost make words (but don't quite). Other moments there are words used to describe bird movement (but not quite). Then there are sounds made which are close to calls the bird makes (but not really). Photographs accompanying the more fragmented sounds are increasingly pixelated. The images, in their imperfect state, operate as the visual equivalent of an experience words cannot account for, as though it is knowledge and classification structures that alter the relation we adopt to what is shown, implying an order otherwise not present. To some extent this hints at the expanded, spillage of experience outside a linguistic equivalent. This evidences the limits of how the world appears to us and, in turn, our limited engagement with birds (and the world). Bennett is harnessing the embodied experience of attending to 'what happens' deploying performative means, via the combination of image and movement, to evidence the complexity of experience.

Argentine writer Jorge Luis Borges' anti metaphysical fictional character, Ireneo Funes, in the short story 'Funes the Memorious' (1964) shares a similar attitude. The misfortunate farmer, Funes, suffers a horse-riding accident and is eventually killed by lung congestion. Funes' perceptive capabilities are second to none. He is able to 
perceive minute details; foam bubbling up in the water droplets of a protruding oar; individual hairs in the mane of a pony. As philosopher Adriana Cavarero in 'For More than One Voice: Toward a Philosophy of Vocal Expression' (2005) points out, Funes couldn't comprehend the generalising function of language. That the word dog might incorporate many animals of differing size and form, yet also describe canine apprehension from various angles was unthinkable. For Funes, the 'human language [was] basically equivocal, imperfect, false' (ibid., p.52) due to the impossibility of language to account for 'the uniqueness of each existent' or 'the active becoming - of typical living things' (ibid., p.48). Funes's world was one of constant flux and change. The stability and congruity that language implied did not serve his purpose. According to Cavarero, for Funes,

the perfect language would be that which assigns a unique name to the instantaneous uniqueness of every thing [...] the sonorous copy of a multiple and restless becoming [...] a polyphony of the world in a human voice. (ibid., p. 51)

The tone in Bennett's voice implies a similar air of dissatisfaction. There are always more variables in the image, an excess that cannot be articulated by words. This is particularly clear when a sequence of images of black-coloured birds are displayed, as Bennett names them, 'crow / rook / crow and other / blackbirds and a / black... bird'. The sequence produces some hilarity amongst the audience, collective recognition - we have all been there - clumsy in our articulation of what we see. Images flit from one to another depicting birds that are reasonably congruous whilst, at the same time, also drawing attention to the inability of language to distinguish the singular individuality of each one which, despite their similarities, do harbour individual characteristics. Bennett's use of tone indicates critical distance between the use of language and language's inadequacy to account for the multiplicity of experience and the plurality of difference available to experience.

16 Coughs occur when the screen is delayed or left lingering on an image for a little too long. It is the kind of cough reminiscent of those issued between co-performers to indicate error or difficulty with what is happening on stage. The coughs issued by Bennett, however, have a different quality and structurally serve to draw attention to a potential error or inadequacy. Here, Bennett's cough serves as a prompt to the unseen force of the technological apparatus that switches the slideshow back and forth, occasionally jamming or holding on to one particular image for too long. This is often the long shot of the bird table, or the fence. Again, Bennett is encouraging us to linger in perception, to extend our attention. The repeated use of the cough evidences the negotiated orchestration between the technological apparatus hosting the slide show and the voice. Bennett's cough punctuates any further illusion of smooth and seamless representation. The cough underscores the act of lingering longer on one image rather than highlight a mistake or problem within the piece, serving to further encourage our turn towards how perception is composed and in operation here.

\section{The Affective Experience of Becoming Bird}

As Slideshow Birdshow progresses there are more fragmented close-ups featuring different parts of each bird's anatomy: 'crown grey cheeks / whitish nape a rich dark chestnut', 'beak / beak yellowish / beak can also be (beak can also be)'. Markings and body parts appear on the slides in great (though out of focus) detail, the kind of detail 
you might imagine Funes to possess without the aid of a camera or projector. The words, largely adjectives, do not quite fit, the description attempts to match the image present, but always elude it. A vibrancy occurs, the words try to catch up. This vibrancy is reflected in the rising and falling intonation present in Bennett's voice. As descriptions become more elaborate, the voice also becomes more hurried, 'because of / copious / pale / scaly feather / margins on / upper parts', what we hear in the auditorium is increasingly fragmented, and of less direct communicative sense. The words attempt to account for what ornithologists might term as 'jizz'. This term refers to the overall general impression of an animate or inanimate object. Jizz cannot be clearly defined and it may emerge from a single characteristic, or combination of several (MacDonald 1996). Ornithologists learn the jizz of birds from many hours spent in the field. Bennett's staging of adjectives serves to evidence the shortcomings of the linguistic unit outside of the representative nature of the signified, outside of logocentrism. Adjectives, typically used to describe birds and their behaviour, cannot accommodate the affective experience of the nonhuman.

As the piece draws to a close, words accompanying the images become increasingly fractured, 'He-he / fly / b back / h-r-ha'. Words used are not afforded their usual weight or rhythm and it is almost impossible to hear what is being said 'bit like a flute / going brip / beak'. Deciphering what is said is rendered secondary, as the fractured sounds featured do not necessarily attribute meaning to what is shown in the slides. These sounds, at times nonsensical, evoke a sensorial engagement with nonhuman beings. An affective, emotive atmospheric is fostered, incorporating an essence of movement further alluding to the behaviour of being bird. Language, or more accurately, the voice does something outside of its usual semantic role. Bennett's voice does not attempt to classify or assign meaning to the visual; instead, her voice gives an essence of what becoming bird, or the experience of being bird might be like. These nonsensical sounds evoke a greater sense of the behaviour of the bird; its movement and attributes are experienced as fractured consonants rubbing against each other, or as flighty vowels, highlighting an internal discordance. The repeated sounding of letters is devoid of the need to create completely audible words or sentences. Her voice incorporates an essence of the quality (or lack thereof) evident in the images as it becomes increasingly less stable interrupting its categorical inclinations. This instability, revealed in Bennett's use of stuttering and irregular rhythms, exposes a sense of reciprocal affect apparent in both as image and voice modify each other, pressing down and, by embodying this in performance, ultimately hint at their mutual entanglement.

\section{Conclusion}

19 Fleeting and unstable 'retro-like' images appear throughout Slideshow Birdshow in an unpredictable erratic rhythm that interrupt Bennett's efforts to describe and effectively articulate the nuances of common garden birds and their behaviour. Images, words and sounds fail to account for each other throughout. This results in the emission of increasingly fragmented phrases and sounds that gradually unfold becoming more and more birdlike. The non-linguistic elements of the piece, the inability of language to account for what is experienced and the emergence of another kind of technological force driving the generation of material are the focus here. The 
combination of images and words alongside Bennett's vocal techniques, the coughs and use of tone indicate a sensorial mode of engagement with the world, one that lies outside classifying structures and systems of representation. Language in this instance is not used for purposeful communication, or to share specific perceptive insights but to open possibilities for engagement with the phenomena of the world. Bennett's work serves to highlight what Dewsbury claims as the main ambition of non-representational theory, namely the ability to, 'think an experience and to present thinking in an experience so as to think as experience.' (2010, p. 151). The use of live performance and minimalistic staging allow Bennett to occupy this opening onto experience and to therefore move beyond the clumsy restraints of language to actively vocalise the relationship and interrelationship between the human and nonhuman. By pursuing a performative writing practice that prioritises attunement, the micromovements and vibrations in operation within language are brought to the fore amplifying, extending and making tangible affective forces occurring in the moment as phenomenal experiences take place. In cultivating a sensitivity to the circulation of aural relations through a writing practice motivated by listening, it is possible to grasp an essence of the performative and affective aspects of 'what happens' in the moment of perception. By using a framework of aural attunement I have fostered a critically intimate approach, via listening, that underscores the value of the how of presentation. This, in turn, evidences that it is less important to uncover a meaning whose equivalence has an exact utterance as a longer, more drawn out, attentive engagement can offer crucial insights into nonhuman species behaviour. Atmosphere and affect are foregrounded as key components of how experience is constituted and lived through. Pulse, pace and rhythm are not coincidental conditions of being but intrinsic to our porous relation with nonhuman species. By attuning to the frequencies and rhythms of nonhuman beings, as suggested in Slideshow Birdshow, a proximity that is somehow subtler yet more entwined than the demonstrative relations suggested in our clumsy reliance on whole linguistic units is experienced.

\section{BIBLIOGRAPHY}

Anderson, Ben \& Harrison, Paul. 2010. The Promise of Non-Representational Theories. In: Anderson, Ben \& Harrison, Paul (eds.) Taking-Place: Non-Representational Theories and Geography. London: Routledge. p. 1-34.

Bennett, Emma. 2013. Slideshow Birdshow (2013) | Performance / Trailer [online]. Available online at: https://emmabennettperformance.wordpress.com/2013/02/17/slideshow-birdshow/ (consulted on April 19, 2021).

Bennett, Emma. 2014. IAMTHEMAKEUP / Camaradefest II 2014 | PERFORMANCE VIDEO [online]. Available online at: https://emmabennettperformance.wordpress.com/2014/10/25/ performance-with-holly-pester-camaradefest-ii-251014/ (consulted on April 5, 2021). 
Bennett, Emma. 2019. Bird Talking? Finding Speechfulness in the Songs of Birds. Performance Research 24 (1). p. 94-103. https://doi.org/10.1080/13528165.2019.1593739.

Borges, Jorge. 1964. Labyrinths: Selected Stories and Other Writings. New York: New Directions.

Boyd, P. Candice \& Edwardes, Christian. 2019. Creative Practice and the Non-Representational. In: Boyd, P. Candice, \& Edwardes, Christian (eds.) Non-Representational Theory and the Creative Arts. Singapore: Palgrave Macmillan UK. p. 1-15.

Cavarero, Adriana. 2005. For More than One Voice: Towards a Vocal Philosophy of Expression [Translated by Paul Kottman]. Stanford, California: Stanford University Press.

Collins, Rebecca. 2017. Sound, Space and Bodies: Building Relations in the Work of Invisible Flock and Atelier Bildraum. M/C A Journal of Media and Culture 20 (2) [online]. Available online at: https://journal.media-culture.org.au/index.php/mcjournal/article/view/1222 (consulted on December 14, 2021).

Collins, Rebecca. 2018. Aural Spatiality and Sonic Materiality: Attending to the Space of Sound in Performances by Ivo Dimchev and Alma Söderberg. Contemporary Theatre Review 28 (2). p. 165-78. https://doi.org/10.1080/10486801.2017.1412952.

Collins, Rebecca \& Linsley, Johanna. 2019. Stolen Voices Is a Slowly Unfolding Eavesdrop on the East Coast of the UK. Arts 8 (4): 140. [online]. Available online at: https://www.mdpi.com/ 2076-0752/8/4/140 (consulted on December 14, 2021). https://doi.org/10.3390/arts8040140.

Dewsbury, John-David. 2010. Language and the Event: The Unthought of Appearing Worlds. In: Anderson, Ben \& Harrison, Paul (eds.) Taking-Place: Non-Representational Theories and Geography. London: Routledge. p. 147-160.

Haydon, Andrew. 2012. 'Postcards from the Gods: Forest Fringe at the Gate - 9'. Emma Bennett Bird Talk (blog). [online]. Available online at: http://postcardsgods.blogspot.com/2012/04/forestfringe-at-gate-9.html (consulted on June 9, 2020).

Home-Cook, George. 2015. Theatre and Aural Attention: Stretching Ourselves. Palgrave Macmillan UK.

Lorimer, Hayden. 2005. Cultural Geography: The Busyness of Being "More-thanRepresentational”. Progress in Human Geography 29 (1). p. 83-94. http:// dx.doi.org.ezproxy.is.ed.ac.uk/10.1191/0309132505ph531pr.

Lorimer, Hayden. 2008. Cultural Geography: Non-Representational Conditions and Concerns. Progress in Human Geography 32 (4): 551-59. http://dx.doi.org.ezproxy.is.ed.ac.uk/ 10.1177/0309132507086882.

Macmillan, Ian. 2012. The Verb. BBC Radio 3. Available online at: https://www.bbc.co.uk/ programmes/b09yhgnf (consulted on December 16 2021).

McDonald, David. 1996. The Etymology of “Jizz". Canberra Bird Notes 21. p. 2-11.

Noë, Alva. 2004. Action in Perception. MIT Press.

Phelan, Peggy \& Lane, Jill 1998. The Ends of Performance. New York: New York University Press.

Phelan, Peggy. 1997. Mourning Sex: Performing Public Memories. London: Routledge.

Pollock, Della. 1998. Performing Writing. In: Phelan, Peggy \& Lane, Jill (eds.) The Ends of Performance. London; New York: NYU Press. p. 73-103.

Serres, Michel. 2016. The Five Senses: A Philosophy of Mingled Bodies. London: Bloomsbury. Spatz, Ben. 2015. What a Body Can Do. London; New York: Routledge. 
Spatz, Ben. 2019. Notes for Decolonizing Embodiment. Journal of Dramatic Theory and Criticism 33 (2). p. 9-22. https://doi.org/10.1353/dtc.2019.0001.

Stewart, Kathleen. 2007. Ordinary Affects. London: Duke University Press.

Stewart, Kathleen. 2011. Atmospheric Attunements. Environment and Planning D: Society and Space 29. p. 445-453.

Terada, Rei. 2009. Looking Away: Phenomenality and Dissatisfaction, Kant to Adorno. Cambridge, Mass: Harvard University Press.

The Voice Symposium on Resonance FM... on You Tube. 2012 [online]. Available online at: https:// rorschachaudio.com/2012/11/28/voice-resonance-fm-1/ (consulted on April 18, 2021).

Thrift, Nigel J. 2008. Non-Representational Theory: Space, Politics, Affect. London: Routledge.

\section{ABSTRACTS}

In this article aural attunement is put forward as a means of performative writing to attend closely to affective relations with nonhuman entities (namely birds). Embodied knowledge harnessed in the writing aims to emulate the experience of being a listening-spectator at Slideshow Birdshow (2013), a solo contemporary performance piece by Emma Bennett. Whilst it is recognised that non-representational theory is a catch-all term to describe affect, atmosphere, and lived experience occurring in the social and relational aspects of our daily lives, the articulation of such dimensions are complicated and not fully translatable into words. Here it is argued, through a critically-intimate writing practice, that contemporary performance and performative writing have much to offer to the ongoing debates within human geography in relation to this. The use of aural attunement to attend to micro-movements, vibrations, rhythm and tone indicate a more sensorial engagement thereby highlighting our affective relations with the nonhuman.

Dans cet article, l'accordage auditive est mise en avant comme un moyen d'écriture performative qui prête attention aux relations affectives nouées avec des entités non humaines (à savoir, les oiseaux). La connaissance incarnée exploitée dans l'écriture vise à émuler l'expérience d'être un spectateur-auditeur dans Slideshow Birdshow (2013), une performance contemporaine solo d'Emma Bennett. S'il est reconnu que la théorie non représentationnelle est un terme fourre-tout pour décrire l'affect, l'atmosphère et l'expérience vécue dans les aspects sociaux et relationnels de notre vie quotidienne, l'articulation de ces dimensions est compliquée et ne peut être entièrement traduite en mots. Dans cet article, nous soutenons, par le biais d'une pratique d'écriture critique et intime, que la performance contemporaine et l'écriture performative ont beaucoup à offrir aux débats actuels au sein de la géographie humaine à ce sujet. L'utilisation de l'accordage auditive pour prêter attention aux micro-mouvements, aux vibrations, au rythme et au ton indique un engagement plus sensoriel, soulignant ainsi nos relations affectives avec le non-humain.

\section{INDEX}

Keywords: performative writing, listening, performance, attunement, non-representational theory, affect

Mots-clés: écriture performative, écouter, performance, accordage, théorie non représentationnelle, affect 


\section{AUTHOR}

\section{REBECCA COLLINS}

Rebecca Collins is an artist researcher. Her main research interests are in listening, performance, sound studies, and creative/critical writing. Her work focuses on the dynamics of the sonic operating within specific environments to explore methodologies of writing, and making contemporary performance. Rebecca is interested in how critical, fictional and performative interventions might cultivate attention toward our contemporary condition. She is the recipient of a Royal Society of Edinburgh Saltire Early Career Fellowship (2022-23) and lecturer in contemporary art theory at Edinburgh College of Art, University of Edinburgh. She is currently completing on her first book publication on sonic detection. Contact: Rebecca.collins@ed.ac.uk 